\title{
Sustainable Management of Eutrophic Lakes and Reservoirs
}

\author{
Tyler Wagner, Larry E. Erickson \\ Department of Chemical Engineering, Kansas State University, Manhattan, Kansas, USA \\ Email: thwagner213@gmail.com, lerick@ksu.edu
}

How to cite this paper: Wagner, T. and Erickson, L.E. (2017) Sustainable Management of Eutrophic Lakes and Reservoirs. Journal of Environmental Protection, 8, 436-463.

https://doi.org/10.4236/jep.2017.84032

Received: March 23, 2017

Accepted: April 27, 2017

Published: April 30, 2017

Copyright $\odot 2017$ by authors and Scientific Research Publishing Inc. This work is licensed under the Creative Commons Attribution International License (CC BY 4.0).

http://creativecommons.org/licenses/by/4.0/ (c) (i) Open Access

\begin{abstract}
Eutrophication of lakes and reservoirs is a major water quality problem that poses significant environmental, economic and social threats around the world. Monitoring and managing lakes and reservoirs to prevent or limit eutrophication, therefore, has significant value. The literature has been reviewed to study ecological engineering and management methods that have been and can be applied to improve water quality. Ecological engineering has the potential to be utilized to improve the design and operation of lakes and reservoirs through monitoring and active management of biological, chemical and physical components. Phosphorus concentrations can be reduced by effective and sustainable management practices to improve water quality.
\end{abstract}

\section{Keywords}

Eutrophication, Harmful Algal Blooms, Cyanobacteria, Ecological

Engineering, Biomanipulation

\section{Introduction}

This manuscript includes a review of the literature on eutrophication and water quality in lakes and reservoirs [1]-[132].

Eutrophication is the increase in the rate of supply of organic matter to a ecosystem because of excess enrichment of nutrients, particularly phosphorus and nitrogen, within a body of water such as a lake or reservoir [72] [122]. High concentration of phosphorus is a major problem in many lakes and reservoirs [8] [89] [110]. This can lead to a host of detrimental effects with the most notable being increased productivity and biomass of phytoplankton, including algae [97] [101]. This can result in other adverse effects such as reduced oxygen levels in the water once the algae die, deaths of other organisms such as fish due to the reduced oxygen levels, taste and odor problems with drinking water, and re- 
duced recreational opportunities because of aesthetic issues and potential toxicity levels [22] [65] [97].

Eutrophication is one of the major water quality problems on our planet [20] [26] [67]. Eutrophication is the cause of about $60 \%$ of impacted rivers and about half of impacted lake area in the United States [97]. It is also the most common water quality problem in estuaries in the United States and affects water bodies across the globe [98]. In China, $85.4 \%$ of 138 lakes with an area $>10 \mathrm{~km}^{2}$ were eutrophic [16].

Climate change is likely to have significant effects on eutrophication [126]. The effects will vary from lake to lake and with seasons. Increased temperature and lengthened growing seasons are likely to increase algal abundance even more [34]. Increases in heavy precipitation events will cause more runoff and carry more nutrients into lakes and reservoirs [112]. Increased frequency and severity of droughts will cause water to stagnate which increases residence time of water and improves conditions for algal blooms. Warming may also benefit zooplankton and macrophyte growth, among other potentially positive effects. There are many effects that will result from climate change, both positive and negative, and they will likely vary by region but it is important to note that climate change will have an impact on eutrophication and lake and reservoir ecosystems in general [118].

Eutrophication can be studied through a framework of the triple bottom line and its three key elements of economic, environmental and social effects [31]. There are serious environmental effects associated with harmful algal blooms as mentioned above. There are cases where the toxicity hurts or kills animals like dogs, as well as causing illness in humans [100]. Eutrophication also has very important economic effects that need to be considered. Economic losses can come from loss of recreational fishing and boating opportunities, loss of property value due to aesthetic issues, costs to maintain biodiversity that is impacted by eutrophication and costs related to taste-and-odor problems with drinking water. These result in estimated losses of approximately $\$ 2.2$ billion a year in the United States alone, and there are factors that are likely being overlooked or underestimated [27]. Meanwhile, costs are estimated at between $\$ 150$ million and \$250 million a year in Australia and countries around the world face similar economic effects [26]. The social issues can be linked back to the environmental and economic issues as loss of recreation and loss of the aesthetic beauty of lakes and other waterways can negatively affect many people.

There are significant benefits associated with active management of lakes and reservoirs provided this can result in improved water quality [13]. Ecological engineering and active management of lakes and reservoirs can be justified if we consider social, environmental, and economic variables that citizens view as important including property values, water and air quality, aesthetic value, taste and odor, turbidity, recreational value, health impacts and regulatory requirements [92].

A crucial aspect of managing eutrophication and freshwater harmful algal 
blooms (FHABs) anywhere is the reduction of the external loading of nutrients, particularly phosphorus and nitrogen. Excess external nutrients come from sources such as agricultural run-off, wastewater, livestock farms, atmospheric deposition and urban centers [98] [130]. There are a number of ways that these sources and the runoff of nutrients can be managed [2]. Free water surface wetlands (FWSW) and constructed lakes can be utilized as buffer zones between nutrient sources and lakes or reservoirs [52] [114] [115]. FWSW can serve as a cheap, environmentally sustainable passive treatment system. Wastewater can also be effectively treated through wastewater treatment facilities. Treatment facilities or better management of waste from hog farming and other livestock farms can reduce the levels of nutrients that enter water bodies [56]. More efficient application of fertilizers can also limit the amount of nutrients that enter lakes and reservoirs. Aquatic vegetable beds are another way that influent water can be treated [100]. In the aquatic vegetable bed set up, plants are grown in channels that untreated water is run through. The plants present are able to filter the water and then are harvested to remove the nutrients from the system and can be sold for income. Similarly, algal turf scrubbing is a system that grows algae in shallow raceways to treat wastewater [1]. The algae can then be harvested and utilized as a source for biofuels or other economic purposes. These represent many of the methods to control external loading of nutrients into lakes and reservoirs. It is a very important aspect of the management of eutrophication and any control of eutrophication in water bodies should start with a reduction of external nutrient loading. Yet even if external nutrient loads are reduced, additional management and monitoring within the lake or reservoir system needs to be conducted.

Lakes and reservoirs are dynamic systems and must be consistently monitored and managed. The issue of eutrophication presents an important challenge that many governments, organizations and people have already dedicated time, money and effort to work to control. It is important that active management and control efforts continue and are refined to be more efficient and effective. In this paper, we have attempted to draw on and evaluate the many monitoring and control methods that have been utilized and to make use of the information in development of management plans that can be used or investigated further in future field studies.

\section{Characterization of the Ecosystem}

Lakes and reservoirs are complex ecosystems with numerous physical, chemical and biological factors that need to be understood for management purposes.

\subsection{Physical Ecosystem}

One important aspect to consider in characterizing a lake or reservoir is the flow of water into and out of the lake. The amount of evapotranspiration and the mean residence time may be important to consider as well. The mean residence time of the water in the lake can be estimated using the volume of water present 
divided by the flow rate into the lake. Under high flow conditions, the mean residence time of water will be smaller which could limit the growth of slow-growing phytoplankton such as cyanobacteria, yet more nutrients and pollutants could be carried into the water body [76] [77].

The physical characterization also includes the depth and area of the lake, as well as the mixing in the lake associated with flow, wind and thermal conditions. Temperature is an important variable because chemical and biological rate processes vary with temperature. It also may be an important factor as higher temperatures can lead to longer growth periods and favor cyanobacterial growth [76].

\subsection{Chemical Ecosystem}

Understanding phosphorus and nitrogen are keys to understanding eutrophication in lakes and reservoirs. Phosphorus and nitrogen are the two nutrients that in a mesotrophic lake would likely be limiting phytoplankton growth to more natural levels. When these nutrients are at elevated levels, phytoplankton are able to grow more abundantly. There are indications that phosphorus is the key limiting nutrient to be managed in lake and reservoir ecosystems [90] [91]. In a study of a lake in China, combinations of phosphorus, nitrogen and iron were added to water samples drawn from the lake [123]. Phosphorus alone was enough to result in significant algal growth while nitrogen and iron alone resulted in very little algal growth. Phosphorus and nitrogen added together resulted in the greatest amount of algal growth, indicating that phosphorus is the key limiting nutrient and nitrogen is the second most important nutrient. Therefore, it seems to be most important to reduce phosphorus levels, with nitrogen levels being a little less significant. Total nitrogen to total phosphorus ratios are also believed to have an impact on the phytoplankton species present and are a good indicator of phytoplankton growth response [18].

Internal loading of nutrients can be a major factor in keeping lakes eutrophic; sometimes even despite reductions in external nutrient loading [98]. Internal loading can often be due to high levels of disturbances due to wind-waves and resuspension [45] [85]. These physical disturbances can cause sediment that had previously settled to reenter the water column and become available to phytoplankton for nutrient use.

Chemical concentrations of phosphorus, nitrogen, dissolved oxygen (DO), biochemical oxygen demand (BOD), chlorophyll $a$ and microcystin have value in the characterization of water quality in a lake or reservoir ecosystem. Total suspended solids (TSS), total dissolved solids (TDS) and $\mathrm{pH}$ are also often measured as important water quality variables. Understanding these physical and chemical characteristics of lakes and reservoirs is important in monitoring and management efforts.

\subsection{Biological Ecosystem}

It is also important to have a good understanding of the biological interactions 
within a lake or reservoir before attempting to manage it. Trophic interactions within lakes and reservoirs are very complex with a wide diversity of organisms filling different roles in various lake and reservoir ecosystems [21]. Therefore, it is important to understand the basic relationships of common trophic levels but to also know that the trophic structure will likely differ from one lake ecosystem to the next.

The trophic level that is a major focus of our study are the phytoplankton. Phytoplankton are microscopic autotrophic organisms and can be responsible for FHABs [39]. Certainly not all phytoplankton are harmful as they are a necessary component of the lake ecosystem, photosynthesizing sunlight and converting it along with carbon dioxide into organic compounds that can be consumed by heterotrophic organisms in the water. Yet as discussed, when they occur in large numbers they can form FHABs. There are a few species in particular that are particularly harmful and are commonly the culprits of FHABs, as shown in Table 1. Cyanobacteria, often called blue-green algae, are a phylum of particularly harmful phytoplankton that often become the dominant group of phytoplankton in eutrophic lakes [97]. Cyanobacteria produce toxins, called cyanotoxins, which can be dangerous to other marine life, as well as other animals such as dogs and humans [62]. There have been a number of cases of animal sicknesses and deaths, fish kills and even humans suffering from illnesses due to exposure to cyanotoxins [62] [113]. One of the most common types of peptide toxins are microcystins but there are a number of other types of toxins, as seen in Table 2.

Table 1. Common phytoplankton and their effects in eutrophic lakes (Modified from Lopez et al., 2008, [62]).

\begin{tabular}{|c|c|c|}
\hline $\begin{array}{c}\text { Inland HAB Taxa } \\
\text { (Specific organisms of concern) }\end{array}$ & Adverse Impacts & Toxins \\
\hline Cyanobacteria & $\begin{array}{l}\text { Human and animal health } \\
\text { impacts; water discoloration; } \\
\text { unsightly and foul-smelling } \\
\text { scums; hypoxia from high } \\
\text { biomass blooms; taste-and-odor } \\
\text { problems in drinking water } \\
\text { and farm raised fish }\end{array}$ & $\begin{array}{c}\text { Hepatotoxins } \\
\text { (include microcystins), } \\
\text { neurotoxins, cytotoxins, } \\
\text { dermatotoxins, respiratory } \\
\text { and olfactory irritant toxins }\end{array}$ \\
\hline $\begin{array}{c}\text { Haptophytes } \\
\text { (e.g., Prymnesium parvum) }\end{array}$ & Fish kills & Ichthyotoxins \\
\hline Chlorophytes & $\begin{array}{l}\text { Discolored water, localized hy- } \\
\text { poxia }\end{array}$ & -- \\
\hline Macroalgae & $\begin{array}{l}\text { Unsightly and foul-smelling } \\
\text { mats, localized hypoxia, clogged } \\
\text { water intakes }\end{array}$ & -- \\
\hline Euglenophytes & Discolored water, fish kills & Ichthyotoxins \\
\hline Dinoflagellates & Fish kills & -- \\
\hline Diatoms & $\begin{array}{l}\text { Produces large amounts } \\
\text { of extracellular stalk material } \\
\text { resulting in ecosystem and } \\
\text { economic impacts }\end{array}$ & -- \\
\hline
\end{tabular}


Table 2. Common cyanotoxins and the possible health effects (Modified from Lopez et al., 2008 and Zanchett and Oliveira-Filho, 2013 [62] [131]).

\begin{tabular}{|c|c|c|}
\hline Toxin & Short Term Health Effects & Long Term Health Effects \\
\hline Microcystins (Hepatotoxin) & $\begin{array}{c}\text { Gastrointestinal, liver } \\
\text { inflammation and hemorrhage } \\
\text { and liver failure leading to } \\
\text { death, pneumonia, dermatitis }\end{array}$ & $\begin{array}{l}\text { Tumor promoter, liver failure } \\
\text { leading to death }\end{array}$ \\
\hline Nodularins (Hepatotoxin) & Similar to microcystins & Similar to microcystins \\
\hline Saxitoxins (Neurotoxin) & $\begin{array}{l}\text { Tingling, burning, numbness, } \\
\text { drowsiness, incoherent } \\
\text { speech, respiratory } \\
\text { paralysis leading to death }\end{array}$ & Unknown \\
\hline Anatoxins (Neurotoxin) & Similar to saxitoxins & $\begin{array}{l}\text { Cardiac arrhythmia } \\
\text { leading to death }\end{array}$ \\
\hline $\begin{array}{l}\text { Cylindrospermopsin } \\
\text { (Hepatotoxin) }\end{array}$ & $\begin{array}{c}\text { Gastrointestinal, liver } \\
\text { inflammation and hemorrhage, } \\
\text { pneumonia, dermatitis }\end{array}$ & $\begin{array}{l}\text { Malaise, anorexia, liver } \\
\text { failure leading to death }\end{array}$ \\
\hline $\begin{array}{l}\text { Lipopolysaccharide } \\
\text { (Dermatotoxin) }\end{array}$ & Gastrointestinal, dermatitis & Unknown \\
\hline Lyngbyatoxins (Dermatotoxin) & Dermatitis & Skin tumors \\
\hline
\end{tabular}

These toxins can cause a wide range of dangerous short and long term health effects ranging from tingling and burning sensations to liver failure or cardiac arrhythmia that can lead to death [113]. Cyanobacteria have some advantageous characteristics that help explain why they are so often the main phylum present in FHABs. They are some of the larger phytoplankton which, along with their toxicity, results in cyanobacteria being grazed upon less by zooplankton than other phytoplankton [34]. Cyanobacteria often grow better at higher temperatures than other phytoplankton, which represents cause for concern with the rising temperatures due to global climate change [76]. They can also be more buoyant than other phytoplankton species which leads to their accumulation near the surface, giving them more access to sunlight and blocking the light from other phytoplankton species [76]. Another important advantage that phytoplankton from the cyanobacteria phylum have is that many are nitrogen-fixers which means that if nitrogen levels are reduced, especially in the absence of phosphorus reductions, blue-green algae will be able to survive and even thrive as they can outcompete the many phytoplankton species that are not nitrogenfixers [91]. This is also another important reason why phosphorus reduction is more important than nitrogen reduction as a management strategy.

There are other species of phytoplankton that can make up harmful algal blooms, as Table 1 shows. One species in particular that is becoming more prevalent is Prymnesium parvum, or golden algae. Golden algae are dangerous because they produce a toxin called prymnesin and the species has been responsible for fish kills in Texas regularly for the past 13 years and is confirmed to be present in at least nine other states [62]).

The other primary producers in lake and reservoir ecosystems are macro- 
phytes, aquatic plants that grow in or near the water. Macrophytes can be considered submerged, floating or emerging depending on the region of the lake or reservoir they grow in and they serve many functions within the ecosystem. Macrophytes can serve as a buffer zone at the edge of the lake, as a hiding area for zooplankton that can feed on phytoplankton, as a sink for nutrients such as phosphorus and nitrogen, competition against phytoplankton and a stabilizer of the sediment and the nutrients it contains [51] [60]. Because of the many roles they can play they are a target for management in restoration, including in biomanipulation, a management strategy that will be discussed later.

Zooplankton are heterotrophic organisms that feed on phytoplankton, macrophytes and other zooplankton. Since they feed abundantly on phytoplankton, they can serve as an important control on phytoplankton populations. They are also a vital food source for larger organisms including numerous species of fish. There is often a great deal of diversity in the types of zooplankton present and this diversity and the abundance of different species can change due to a number of factors. For example, fish will often consume more of the larger zooplanktonic organisms, reducing their abundance while smaller species of zooplankton become more plentiful. In lakes with more macrophyte cover, though, larger zooplankton may be able to find more cover and not be reduced by predation as much [94]. Daphnia is one common genus of zooplankton that can grow to 1 - 5 millimeters in length, which is relatively large for zooplankton [29]. Daphnia are an example of a very effective predator of phytoplankton but also one that can often be reduced in abundance by predation by fish species [35].

Fish are another important part of the lake and reservoir trophic web. There are a few different classifications of fish that should be considered. Some fish are considered to be planktivorous fish, feeding mainly on zooplankton, macrophytes or phytoplankton. Other fish are called piscivorous fish and these feed on other fish, including planktivorous fish. Omnivorous fish are general feeders and can feed on other animals, plants and algae. Benthivorous fish feed on benthic organic matter and disturb sediments which increase turbidity. Lakes dominated by planktivorous fish will generally have a greater algal biomass than lakes dominated by piscivorous fish [97]. Planktivorous fish can include particulate feeders and filter feeders such as perch and bluegill and are known to enact grazing pressure on plankton [58]. Studies have shown that lakes and reservoirs with planktivorous fish are generally made up of smaller species of zooplankton due to grazing and that this also has an effect on phytoplankton communities that may be relieved of grazing pressure from larger zooplankton [88]. Piscivorous fish can include species such as bass and pike and are generally top predators in lake and reservoir ecosystems. Piscivorous fish can feed on planktivorous fish and relieve grazing pressure on zooplankton. Omnivorous fish, such as carp, catfish and tilapia, are much more general feeders. These types of fish will often feed on macrophytes, phytoplankton and zooplankton. Understanding the trophic interactions, along with the chemical and physical characteristics of a lake or reservoir, is an important facet of lake and reservoir management. 


\section{Measurements and Methods}

A vital aspect of lake management is monitoring of important variables. Monitoring is needed to properly implement ecological engineering strategies and to know if all variables are within safe limits. There are a variety of indicators that reveal valuable information about a lake or reservoir ecosystem [110]. Measurements should be taken on at least a monthly basis because many variables display natural seasonal variations. It is also advised that measurements be taken at a variety of different locations on the lake or reservoir to get a more representative set of samples. Standard Methods for the Examination of Water and Wastewater is a comprehensive reference for measurements and monitoring of lakes and reservoirs [3]. Additional resources can be found online at standardmethods.org. Organizations including the EPA utilize many of the methods contained within this reference for monitoring of lake and reservoir ecosystems. Additional references include the United States EPA's Nutrient Criteria Technical Guidance Manual: Lakes and Rivers (2000) and the National Lake Assessment: Technical Appendix (2010) [110] [111] [114].

There are many variables that are important to measure when monitoring a lake or reservoir. Air and water temperature, dissolved oxygen (DO) levels, turbidity, $\mathrm{pH}$ and specific conductance should be measured at multiple locations on the lake utilizing a water quality checker [122]. As mentioned before, phosphorus and nitrogen are the two most important nutrients involved with eutrophication so it is important to measure these. For these nutrients, as well as major ions, fecal coliform bacteria, and suspended solids, water samples should be collected and tested in laboratories using standard tests [3] [110] [111] [114] [122].

Active management of the biological populations in the lake should be based on measurements and an understanding of the ecosystem. Thus, biological measurements are needed to understand what organisms are present and how they interact. Chlorophyll a is a key component in the process of photosynthesis and can measure algal abundance even if non-algal organic and inorganic particles are present [48]. Therefore, it is considered to be a very good measure of the presence of phytoplankton in a lake or reservoir ecosystem [128]. Chlorophyll a can be measured using various techniques including high performance liquid chromatography, spectrophotometry and fluorometry [3] [128]. Water samples that are collected should be preserved for microscopic examination for phytoplankton. A vertical tow net or a Schindler-Patalas trap can be used to collect zooplankton samples [122]. Fish populations can be assessed using available methods to monitor populations of fish [83]. Macrophyte vegetation can be measured and characterized according to the EU Water Framework Directive [17]. The ecological quality ratio is a quantitative ratio between the measured value and a defined referenced condition [17]. Kennison et al. (1998) have also reported a sampling method for conducting macrophyte surveys [55]. These monitoring methods are important for understanding the species present.

Water transparency can be measured at multiple locations around the lake using a Secchi disk and a light meter [122]. Oxidation reduction potential (ORP) 
is important for monitoring the biochemical reactions within the ecosystem [10] and can be measured using an ORP electrode [122].

Microcystin is one of the toxins that are produced by many species of cyanobacteria. The World Health Organization has issued an advisory limit for drinking water of $1 \mu \mathrm{g} / \mathrm{L}$ for microcystin [62]. ABRAXIS Test Strip Kit is a valuable test kit that can be used to easily and quickly measure microcystin levels [11].

Methods to measure and characterize populations of fish include electrofishing where electric current is used to capture fish and gillnets [33] [87].

A number of these measurements can be used to classify the trophic state of lakes or reservoirs [50]. The trophic state can range between oligotrophic where the ecosystem is nutrient deficient, to mesotrophic where there is an intermediate amount of nutrients and productivity, to eutrophic where nutrients are in excess. It is important to understand the relationships that exist between nutrient and algal concentrations as these measurements can be used to indicate to lake managers the likely state of a lake or reservoir and indicate any management actions that may need to be undertaken.

Mass balances can be used to help characterize the state of the lake [99]. Vollenweider's mass balance model can be utilized to predict the mass balance of nutrients within a lake or reservoir ecosystem [114]. Balances on phosphorus and nitrogen can provide information on how to effectively remove nutrients by harvesting algae, fish and macrophytes [40] [117]. When making mass balances on nitrogen and phosphorus, it is important to know the $\mathrm{N}$ and $\mathrm{P}$ content of the fish that are harvested. Olin et al. have used $0.8 \% \mathrm{P}$ when working with fish fresh weight (FW) [75]. Sterner and George reported a mean value of $1.5 \%$ P dry weight for cyprinids [102].

Good monitoring practices are important to have a good understanding of the characteristics of a lake, including the physical, chemical and biological aspects as discussed. Once the lake or reservoir system is well understood, it is easier to determine effective and appropriate management strategies. Since inputs to these ecosystems are dynamic with variations in flow and concentration, continuous monitoring and management are needed in order to maintain physical, chemical and biological variables within the desired operating range. Data collected by satellites may be reviewed to identify problems that need to be addressed.

\section{Management Strategies}

Eutrophication has been a noticeable problem for a number of years, and a variety of control methods have been developed [40] [49] [65] [82]. Some are certainly more effective than others while some may have adverse side effects. Some treatments are still in the research stage and have only been utilized on a small scale. As discussed earlier, a vital step in lake and reservoir management is the reduction of external nutrient loading. While reduced external nutrient loading is going to be an important component of nearly any lake or reservoir management plan, external loading often cannot be reduced to the desired level and in- 
ternal nutrient loading can continue to keep a lake or reservoir eutrophic long after external loads have been reduced [45] [46] [51] [64].

An important active management goal is to reduce the concentration of phosphorus in the lake or reservoir system because it is easier to prevent eutrophication when the phosphorus concentration is lower. Therefore, it is important to implement management practices within the lake to effectively mitigate the threat of eutrophication and FHABs. In this section, management practices such as the use of algaecides and chemical flocculants are considered; however, in developing good ecological management plans, greater emphasis should be placed on ecological solutions that control eutrophication sustainably and do not have negative side effects.

\subsection{Physical and Chemical Methods}

One method of control is the application of algaecides, chemicals that are designed to kill algae. There are concerns that algaecides may pose a threat to humans as well and have detrimental impacts to lake and reservoir ecosystems [45]. For example, copper sulfate is a common algaecide and it controls algae by lysing the phytoplankton cell. This can cause the rapid release of toxins contained within algae such as cyanotoxins [47] [109]. These toxins can cause harm to humans that interact with the water and may accumulate in the sediment and water column, proving harmful to aquatic animals and plants. There is also evidence that algae are becoming resistant to the application of algaecides like copper sulfate [38].

Chemical flocculants can be applied to lakes and reservoirs as a clarifying agent to precipitate nutrients and algae from the water column although there are studies that indicate that these treatments are harmful to the ecosystem and may not be effective in the long run [45]. Aluminum sulfate is a commonly used chemical flocculant although there is some dispute over its effectiveness. One study indicated that aluminum sulfate was able to significantly reduce soluble phosphorus from eutrophic water, although it can be expensive due to the need for repeated applications [4]. Other reports indicate that the aluminum sulfate exhibited complete ineffectiveness or effectiveness that lasted between 4 months to 6 years [45] [46]. Aluminum sulfate can be toxic to fish and other organisms and may cause acidified waters and fish kills [5].

There is some research into an integrated approach that combines algaecide and chemical flocculant application. An algaecide like hydrogen peroxide was found to be effective for limiting cyanobacterial blooms while not affecting beneficial phytoplankton like green alga and diatoms as significantly but can't effectively deposit algae to the lake bottom [28]. Meanwhile, sediment clay modified with a chemical flocculant, ferric sulfate, is able to effectively remove cyanobacterial blooms but by itself does not inactivate the algae which leaves them prone to resuspension [121] [124]. When water with cyanobacterial colonies was first treated with hydrogen peroxide and then modified clay sediment, the cyanobacteria were inactivated by the algaecide and then deposited at the bottom 
with a reduced chance of resuspension [121] [124]. This experiment also reported very little cell lysis which is important as to avoid a release of toxins into the water column.

Another control method is the use of modified clays to bind phosphorus to inhibit its use for the growth of cyanobacteria and other phytoplankton. There are a few different modified clay types, including nanosilicate platelets and clay modified by lanthanum [14] [64] [68] [120] [129]. Lanthanum-modified clay has been applied in lakes around the world, including the United States, Australia, and Germany. The modified clay is mixed with water to form a slurry and applied to the lake or reservoir at an approximate ratio of $100 \mathrm{~kg}$ of clay to $1 \mathrm{~kg}$ of phosphorus in the water [8]. As the slurry is applied to the water, it bonds and sequesters the soluble free reactive phosphorus that is present within the water column [64]. It then settles to the lake or reservoir floor where it can bind additional free reactive phosphorus and serve as a cap on any phosphorus that might be released from the sediment, while continuing to sequester the phosphorus it previously bound. Application of this lanthanum-modified clay product has proven very successful in a number of case studies $[8,64]$. It is promising that lanthanum-modified clays have already been shown to be effective on a whole-lake scale but most experiments have been over a short time frame. Since lake management is a long term project, studies should be carried out to determine the longevity of the effectiveness of lanthanum-modified clays.

Nanosilicate platelets (NSP) are a control method made by the exfoliation of natural clay materials and are found to have low mammalian toxicity so as not to negatively impact other organisms [59]. NSP may be very useful as a study found that they were able to both effectively inhibit the growth of cyanobacteria and absorb the toxin microcystin [14]. NSP also reduce turbidity as they enhance settling of cyanobacteria. This helps with water transparency and the growth of macrophytes and other phytoplankton that could result in a healthier lake or reservoir ecosystem. Additional experiments of NSP on a whole lake scale would be beneficial to determine their viability as a lake management strategy.

Destratification, physical removal or harvesting and sediment dredging are also possible control methods although they contain the significant drawback that they are very expensive [71]. Destratification could be done by pumping nutrient and oxygen rich waters from the surface down to the hypolimnion using an axial flow propeller pump [103] [108]. This would not be feasible on a large scale, though. Harvesting the algae when blooms start to develop is another management technique [65]. This is also a relatively expensive method due to equipment, fuel and labor costs and is unlikely to be feasible for larger lakes and reservoirs. One benefit to this method is that many algae have commercial value [43]. Similarly, for sediment dredging, the economic costs would be significant and there would also be negative ecosystem effects, especially to benthic organisms which could lead to effects along the entire trophic web. Studies also suggest that sediment dredging may improve water quality in the short term but is not a viable long term solution [30]. 
While destratification by pumping air through the whole lake may be too expensive and energy intensive, there is a proposed method that is both more economically and environmentally friendly. Solar powered circulation (SPC) uses renewable solar power to circulate the top layer of water to inhibit algal growth [44]. The solar power charges a battery to power the SPC unit's motor and the unit can utilize grid-power during periods of low light incidence. The circulation of water can oxygenate the water and enable aerobic digestion by bacteria. SPC units circulated about $37,850 \mathrm{~L} / \mathrm{min}$ of water and are generally designed to be low maintenance with a relatively long lifetime [74]. They also are relatively economical as they have about a two to four year payback period [44]. SPC has been studied in whole lake experiments and it has proven more successful than copper sulfate at inhibiting algal growth [46]. In these case studies, once SPC was deployed, copper sulfate use, FHABs and taste and odor problems were all reduced. It is important to note that SPC has been less successful in controlling FHABs in shallow aquaculture ponds, shallow ponds with short water residence times and lakes where SPC was only partly deployed [46]. Overall, though, case studies indicate that SPC can be effective at reducing cyanobacteria and taste and odor problems in an economical and sustainable way. While it seems that solar powered circulation offers a long term eutrophication solution that reduces the growth of cyanobacteria, continued whole lake studies are recommended to understand the most effective approaches to implementation.

\subsection{Biological Methods}

Phytoplankton can also be controlled in more natural, biological ways. Strategies that can enhance conditions for predators of phytoplankton or diminish conditions for the phytoplankton themselves can help to control FHABs. One strategy is to add piscivorous fish with the goal of creating a trophic cascade [12] [25] [95]. The theory is that with the introduction of piscivorous fish, planktivorous fish will be reduced which will lower the predation on zooplankton which will then consume more phytoplankton, thereby reducing FHABs. Planktivorous fishes particularly put predation pressure on larger zooplankton. Cyanobacteria are among the larger phytoplankton and are only able to be controlled by larger zooplankton or fish such as tilapia [63], so they thrive when zooplanktivorous fish consume the larger zooplankton, leading to FHABs. Piscivores are able to apply predatory pressure on planktivorous organisms that can influence the trophic webs within lake and reservoir ecosystems [12]. It is rare, though, that a lake or reservoir ecosystem acts so simply that the introduction of piscivorous fish will start a complete top down control of phytoplankton [32]. There are nearly always much more complex trophic interactions that must be carefully considered, particularly in subtropical and tropical lakes and reservoirs [52]. Utilizing piscivorous fish to control phytoplankton may only work in lakes and reservoirs with established macrophyte populations and with less elevated nutrient levels and before phytoplankton blooms have already occurred [127]. At these junctures, the trophic cascade can allow large-bodied zooplankton to do- 
minate and be able to control phytoplankton before large cyanobacteria species dominate and increase to a number that is too large to be controlled by zooplankton alone. In those cases, omnivorous fish such as tilapia and carp can be used to feed on phytoplankton directly [63]. Fish are able to consume large cyanobacteria and other harmful phytoplankton that may not be controlled by zooplankton. Studies have been done that have stocked eutrophic lakes with omnivorous fish and they have seen success in controlling phytoplankton levels, as well as reducing the dominance of cyanobacteria among the phytoplankton [127].

One concern about the use of fish as a control method is that nutrients are added by their excrement [37] [104]. Fish can be harvested so that the nutrients they have consumed are removed permanently from the ecosystem [57] [65]. The removal of planktivorous fish and benthivorous fish has been found to be beneficial because zooplankton grow larger and their population increases. Removal of a significant fraction of the planktivorous fish reduces the amount of excrement from the fish, which can improve light penetration and macrophyte establishment and growth. In some cases removal of $75 \%$ of the planktivorous fish was found to be needed for good results [66] [75]. This reduced the phosphorus concentration in the lake and improved water clarity [66]. Schrage and Downing [93] removed benthivorous fish to decrease suspended sediment and improve water clarity. In the weeks that followed zooplankton biomass increased and their grazing reduced phytoplankton populations. After about two months of zooplankton control, juvenile carp began to reduce zooplankton population. Pedusaar et al. [79] reported beneficial water quality effects from the removal of cyprinids from Lake Ulemiste, the drinking water reservoir for Tallinn, Estonia. The total phosphorus concentration was reduced from $0.050 \mathrm{mg} / \mathrm{L}$ to 0.036 $\mathrm{mg} / \mathrm{L}$. The mean phytoplankton biomass concentration decreased from 15 to 6 $\mathrm{mg} / \mathrm{L}$. In the 2004-2006 removal of fish, $160 \mathrm{~kg} / \mathrm{ha}$ of fish, mostly cyprinids, were removed. Ter Heerdt and Hootsmans [107] reduced benthivorous fish to less than $25 \mathrm{~kg} / \mathrm{ha}$ and piscivorous fish to less than $15 \mathrm{~kg} / \mathrm{ha}$ in a peaty turbid lake. This resulted in an increase of cladocerans such as Daphnia and a decrease in cyanobacteria. The submerged vegetation increased to $30 \%$. In another report [116] 60\% coverage in shallow areas was observed. Rao et al. [87] reported that larger Tilapia should be selectively harvested because the large Tilapia fed on macrophytes while small Tilapia fed on periphyton, seston, and detritus. Small Tilapia that are $6-7 \mathrm{~cm}$ in length are planktivorous. The removal of fish can also be paired with macrophyte restoration. Macrophytes will help take up the nutrients that accumulate on the lake floor from fish excrement, as well as provide a surface for bacteria to grow on that can help consume fish waste and dead fish [85]. Omnivorous fish like carp and tilapia consume zooplankton but they consume a fairly equal amount of phytoplankton, suggesting that they can serve as a useful management method [63] [132] Lu et al. [63] added Tilapia at a density of $3-5 \mathrm{~g} / \mathrm{m}^{3}$ and observed improved conditions because the Tilapia consumed phytoplankton. Finally, it will be important that each lake or reservoir carefully 
considers the species of fish it might use to control FHABs and be sure to avoid introducing an undesirable species.

The restoration of macrophytes is another method of biomanipulation that can be utilized to attempt to control FHABs [6] [69] [124]. Macrophytes are able to improve water quality by adsorbing nutrients through their roots, adsorbing microbes and floating matter through their leaves and stems and precipitating suspended particulates [86]. Macrophytes and their roots can be used to stabilize sediment so that it is less likely to be suspended by wind-induced waves and release additional nutrients that can be utilized by phytoplankton [81, 86]. Planting of macrophytes is one technique that can be used to help maintain the sediment and keep nutrients from becoming resuspended in the water column. In Holland, shallow lakes with macrophyte coverage of at least $5 \%$ of the total benthic zone surface area displayed significantly lower phytoplankton concentrations compared to shallow lakes with less macrophyte coverage [84]. Macrophyte restoration experiments have been attempted in a number of places [23, 80]. When populations of planktivorous fish are reduced substantially to allow zooplankton to control phytoplankton populations and when macrophyte coverage exceeds $30 \%$, water clarity is good and eutrophic conditions are under control [6]. There is a need to harvest planktivorous fish populations regularly to sustain this condition. This harvest removes phosphorus from the lake and allows an effective zooplankton: phytoplankton ratio to be maintained [42]. Table 3 shows fish harvests for several years for several lakes in Finland [75].

The total phosphorus concentration of $0.30 \mathrm{mg}$ P/L has been reported as an upper limit for eutrophic ponds [24]. With good submerged vegetation and biomanipulation to remove sufficient fish to allow large zooplankton to graze on phytoplankton effectively a clear-water condition was maintained for $\mathrm{P}<0.30 \mathrm{mg}$ $\mathrm{P} / \mathrm{L}$.

Perrow et al. [82] points out that a stable steady state improved water quality condition may be established by regular fish removal and by maintaining macrophytes, piscivorous fish, high zooplankton biomass, and lowered phytoplankton biomass at high nutrient loadings. Teissier et al., [106] have reported on the importance of submerged vegetation and zooplankton grazing in reducing phytoplankton concentrations when phosphorus concentrating are of environmental concern.

Many factors such as high nutrient concentrations, strong winds and waves, low transparency that limits photosynthesis and periphyton can inhibit macrophyte growth [15]. Macrophyte restoration alone is likely not going to be a successful management method for eutrophic lakes. There are indications that if a lake is managed to reduce nutrient levels, macrophyte restoration may be successful to help the lake ecosystem reach a stable-state [36] [86]. Improved understanding of appropriate macrophyte species to select for restoration on a whole lake scale will be very beneficial in improving this as a management strategy. Hasan and Chakrabarti [41] have reviewed the literature on aquatic macrophytes as sources of food for herbivorus fish populations. Additional research is 
Table 3. Mass removal catches between growing seasons during 1997-2001 for lakes in Finland.

\begin{tabular}{|c|c|c|c|c|c|c|}
\hline \multirow[t]{2}{*}{ Lake } & \multicolumn{4}{|c|}{ Mass removal catch $\left(\mathrm{kg} \cdot \mathrm{ha}^{-1}\right)$} & \multirow[t]{2}{*}{ Total } & \multirow[t]{2}{*}{ Main species } \\
\hline & 1997-1998 & 1998-1999 & $1999-2000$ & $2000-2001$ & & \\
\hline Takajarvi* $^{*}$ & 37 & 60 & 96 & 54 & 295 & $\mathrm{Ro}, \mathrm{Br}$ \\
\hline Etujarvi* & 50 & 59 & 72 & 75 & 348 & $\mathrm{Ro}, \mathrm{Br}, \mathrm{Pe}$ \\
\hline Otalampi & - & 70 & 44 & 6 & 119 & Ro \\
\hline Rusutjarvi* & 6 & 119 & 76 & - & 201 & $\mathrm{Ro}, \mathrm{Br}, \mathrm{Bl}$ \\
\hline Pusulanjarvi & 36 & 44 & 53 & 41 & 182 & $\mathrm{Ro}, \mathrm{Bl}, \mathrm{Br}$ \\
\hline Enajarvi & 68 & 18 & 58 & 47 & 190 & $\mathrm{Ro}, \mathrm{Br}, \mathrm{Bl}$ \\
\hline Tuusulanjarvi* $^{\star}$ & 190 & 83 & 131 & 63 & 472 & $\mathrm{Ro}, \mathrm{Br}$ \\
\hline Lehijarvi & 1 & 1 & 26 & 61 & 90 & Ro, Bl, Pe \\
\hline Aimajarvi, $\mathrm{A} 1^{*}$ & 23 & 47 & 80 & 106 & 257 & Ro \\
\hline Aimajarvi, $\mathrm{A} 2^{*}$ & 51 & 110 & 38 & 27 & 226 & Ro \\
\hline Hiidenvesi, H1 & 11 & 24 & 6 & 3 & 44 & $\mathrm{Ro}, \mathrm{Bb}$ \\
\hline Hiidenvesi, $\mathrm{H} 2^{\star}$ & 61 & 65 & 147 & 138 & 411 & $\mathrm{Ro}, \mathrm{Bb}$ \\
\hline Hiidenvesi, H3 & 15 & 24 & 56 & 34 & 153 & Sm, Ro \\
\hline Hiidenvesi, H4 & 42 & 23 & 29 & 34 & 121 & $\mathrm{Sm}, \mathrm{Bl}$ \\
\hline
\end{tabular}

The basins where the target catch $\left(200 \mathrm{~kg} \cdot \mathrm{ha}^{-1} 3 \mathrm{yr}^{-1}\right)$ was achieved are indicated with ${ }^{*}$. Total $=$ catches during 1997-2001 (4 years) and also includes catches during growing seasons. Main species comprise at least $20 \%$ of the total catch. $\mathrm{Ro}=$ roach, $\mathrm{Br}=$ bream, $\mathrm{Pe}=$ perch, $\mathrm{Bl}=$ bleak, $\mathrm{Bb}=$ blue bream, and $\mathrm{Sm}=$ smelt. From Olin et al. [75].

needed to develop or determine macrophytes that can be nurtured effectively as part of an ecological engineering approach to water quality improvement in lakes and reservoirs. Macrophytes that have value as harvested products, that can be grown in most lakes and reservoirs and that remove significant amounts of nutrients need to be investigated further.

Seaweed (Porphyra spp.) wild rice (Zizania palustris), and water mimosa (Neptunia Oleracea) are examples of aquatic plant species that may be considered [125]. Morris et al. [69] have investigated the impact of plant harvesting on water quality. Their method of harvesting allowed for the regrowth of the macrophytes. They reported that plant harvesting did not result in a significant increase in Cyanobacteria.

Some plants may be toxic to cyanobacteria such as umbrella plants, Canna and barley straw [45]. Canna and umbrella plants contain alleochemicals that are toxic to cyanobacteria and are able to inhibit their growth [70]. Both of these types of plants are generally terrestrial, though, so a system such as an artificial floating island (AFI) needs to be employed. An AFI is a system where terrestrial or aquatic plants can be grown in floating frames on the surface of the water [61]. While a wide variety of plants could be utilized in this system to remove nutrients from the water, canna and umbrella plants can provide the added benefit of releasing the chemicals that are toxic to cyanobacteria. 
The integrated ecological floating bed (IEFB) is a slightly more advanced system similar to the AFI to utilize macrophytes as a regulatory mechanism for a lake or reservoir while avoiding things that can often restrict macrophyte growth such as waves, water depth and turbidity [60]. Li et al. offers an innovative IEFB design, as seen in Figure 1 [60]. The floating-bed system consists of aquatic or terrestrial plants growing in a hydroponic manner with buoyant frames floating on the surface of the lake or reservoir. Plants take up nutrients directly from the water column while the underwater surface of the plants and a biofilm support structure serve as a base for the attachment of microorganisms which break down organic matter and entrap suspended solids. The plants can also be harvested for use as food or other biomaterial. Additionally, filter-feeding bivalves can be introduced to the system to feed on phytoplankton within the water and can be harvested for food and removal of nutrients from the system. The nutrients that bivalves are able to take out of the system by consuming plankton have to be balanced with the nutrients they add to the system through their excrement, though. Studies have shown that TN and TP are reduced by the IEFB system in comparison to a control, even with the inclusion of the bivalves [60].

Jung et al. [54] have developed an artificial aquatic food web system to remove nitrogen and phosphorus in inlet streams. Their process includes phytoplankton and zooplankton growth in separate chambers with harvesting of the zooplankton.

Jobgen et al. [53] have investigated phosphorus removal by periphyton growing on submerged artificial substrata polypropylene surfaces that are used to remove phosphorus by growing phytoplankton and benthic diatoms on the surfaces. The carriers are removed from the water with the adsorbed biomass.

An ecological engineering approach was employed in Lake Taihu, to utilize both physical and biological strategies to reduce eutrophic conditions in the lake [36]. An enclosure was set up and concrete pilings were built along with the enclosure to help reduce wave power to decrease sediment resuspension [15]. Macrophytes were restored within the enclosure although submerged macrophytes were only partly rehabilitated once the enclosure was removed. Macrophytes planted on floating bamboo rafts and terrestrial species acting as a buffer zone

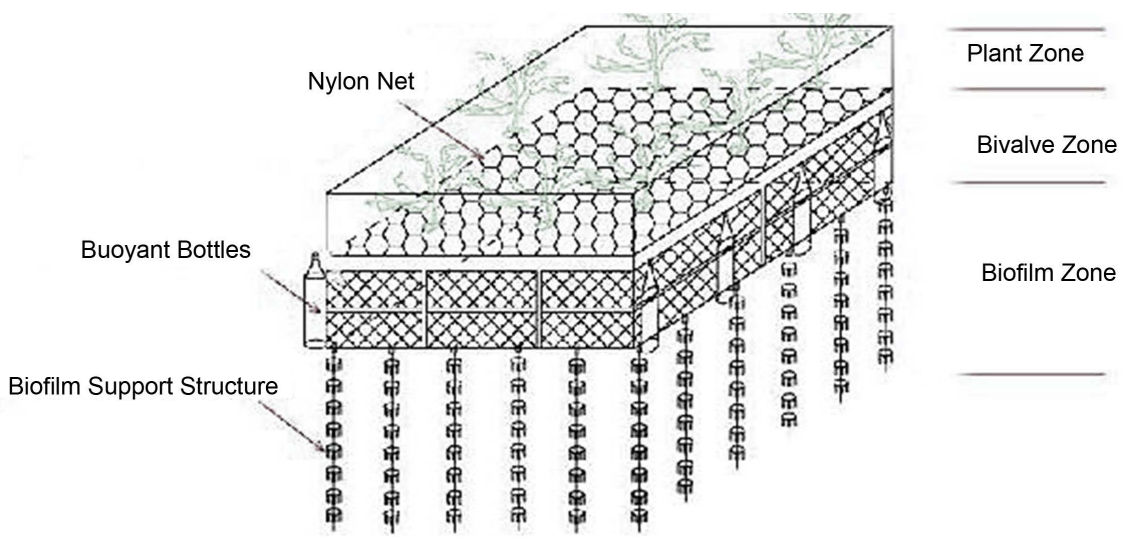

Figure 1. Example of an IEFB (Modified from Li et al., [60]) 
against nutrient runoff, meanwhile, were much more successful. This indicated that macrophyte restoration may simply need some alternative thinking to successfully assist in eutrophication management. Fishing net and other biomimetic mesh was also successful as a medium to adsorb suspended solids and algae and absorb nutrients [15]. It seems that with the complexity that exists within lake and reservoir ecosystems, a single species introduction is unlikely to lead to full control of algal blooms. A more comprehensive and integrated approach is much more likely to prove successful in the management of a eutrophic lake or reservoir ecosystem.

\section{Professional Expertise}

There is a need to have appropriate professional expertise in ecological engineering, aquatic biology and environmental science to lead an effort to apply knowledge that is available to manage water quality in lakes and reservoirs [78]. There is also a need to be able to work cooperatively with all stakeholders because of the influent streams, shore line areas and lake water body as commons that are of value to many different people.

Based on a review of the available literature, actions that reduce nitrogen and phosphorus concentrations in the water are important. This includes efforts to reduce concentrations in inlet flows, removal of $\mathrm{N}$ and $\mathrm{P}$ by harvesting planktivorous and benthivorous fish, and establishment of macrophytes that take up $\mathrm{N}$ and P. Suspended solids concentrations should be reduced by these actions as well. The amount of $\mathrm{P}$ that is removed by reducing the population of planktivorous and benthivorous fish by more than $75 \%$ or to less than $50 \mathrm{~kg} \mathrm{FW} / \mathrm{ha}$ is substantial because the fish represent about $40-50 \%$ of the $\mathrm{P}$ that is present in the water in some lakes [40] [113]. Figure 2 from Van Liere and Janse [117] shows $P$ content in $\mathrm{mg} \mathrm{P} / \mathrm{m}^{2}$ for Lake Loosdrecht in 1987 as well as $\mathrm{P}$ fluxes in $\mathrm{mg} \mathrm{P} / \mathrm{m}^{2}$ per day. Removal of $75 \%$ of the fish reduces $\mathrm{P}$ in the fish population from 150 $\mathrm{mg} \mathrm{P} / \mathrm{m}^{2}$ to $37.5 \mathrm{mg} \mathrm{P} / \mathrm{m}^{2}$ and the $\mathrm{P}$ in the water from 321.5 to $209 \mathrm{mg} \mathrm{P} / \mathrm{m}^{2}$, which is a $35 \%$ reduction. In Figure 2 , the $\mathrm{P}$ in the macrophytes is not included.

The sustainable conditions that are needed to prevent algal blooms depend on the inlet concentrations of $\mathrm{N}$ and $\mathrm{P}$, temperature, mean residence time of the water in the lake, wind conditions, and the surroundings. Where $30 \%$ or greater coverage of macrophytes can be established, this appears to be helpful. Periodic removal of planktivorous and benthivorous fish is helpful to keep fish populations below about 100 - $200 \mathrm{~kg} / \mathrm{ha}$ [7]. Management of fish populations by stocking piscivorous fish (pike, walleye, largemouth bass) and omnivorous fish such as tilapia may be beneficial. Tilapia are herbivorous and will feed on phytoplankton and macrophytes. It is desirable to manage the fish population such that species that have recreational value and food value are produced and harvested. The $\mathrm{P}$ in the harvested fish contributes to the mass balance on phosphorus, and this method of removal is important.

Gulati and van Donk [40] have pointed out some of the beneficial aspects of macrophytes. Macrophytes take up $\mathrm{N}$ and $\mathrm{P}$ from the water and sediments. Ma 


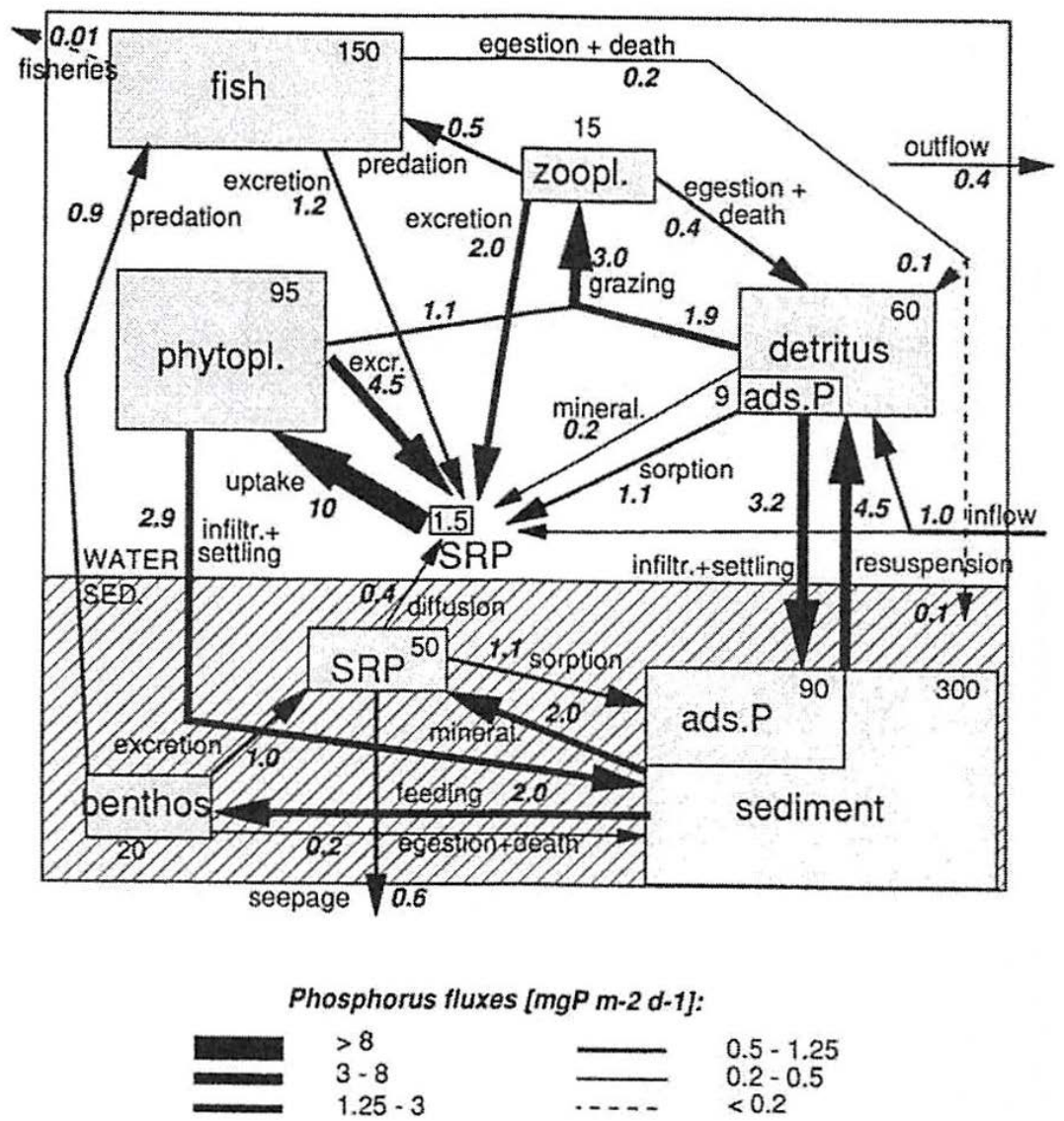

Figure 2. Flow diagram of phosphorus content $\left(\mathrm{mg} \mathrm{P} \mathrm{m}^{-2}\right)$ and fluxes $\left(\mathrm{mg} \mathrm{P} \mathrm{m}^{-2} \cdot \mathrm{d}^{-1}\right)$ between trophic levels, water and sediment of Lake Loosdrecht for the period April-September, 1987, based on mathematical model PC-LOOS (Source: Figure 3 in Gulati and van Donk [40].

crophytes provide food for herbivorous fish, and they provide cover for some larger zooplankton against fish predation. Macrophytes reduce suspended solids concentrations in the water by reducing bioturbation due to benthivores and by reducing water velocity caused by wind. Macrophytes can be harvested to remove $\mathrm{N}$ and $\mathrm{P}$ from the lake. Macrophytes can become so numerous that they reduce the quality of the lake.

The eutrophic conditions that result in harmful algal blooms can be reduced or eliminated by removing $\mathrm{P}$ by harvesting fish regularly to maintain fish populations at the desired density. Desired species may need to be added also to reduce the undesirable impacts of planktivorous and benthivorous fish. If the population size is too large $\mathrm{P}$ concentrations will be higher because of the impact of fish excrement on the $\mathrm{P}$ concentration. If the population size is too small $\mathrm{P}$ removal rate will be too small. The desired density will be between 50 and $250 \mathrm{~kg}$ FW/ha for most lakes. Tatrai et al. [105] have reported multiyear control of phytoplankton by keeping cyprinid fish populations around $100 \mathrm{~kg} / \mathrm{ha}$ with piscivore populations sustained at a biomass ratio $>15 \%$ and total fish biomass $<$ $150 \mathrm{~kg} / \mathrm{ha}$. Macrophytes provide environments that enhance reproduction of 
pike. Vegetation provides a spawning habitat that contributes to spawning success and survival of young [19].

One of the significant challenges is the variation in inlet conditions associated with precipitation and upstream operations. The management of water quality in lakes and reservoirs can benefit from careful consideration of risk management and resilience-based stewardship as recommended by Seidl [96]. This includes anticipatory risk management and consideration of the capacity of a lake to absorb perturbations and retain trophic structure and desired processes over a range of inlet conditions. Uncertainty must be considered because natural events impact water quality significantly.

Climate change has had an impact on the management of lake water quality in Finland [118]. There is a need to consider the impacts of climate change in management plans to reduce eutrophication.

While the published literature contains the results from many studies, there is a need for additional data because of the complexity and large number of variables that have importance for water quality in lakes and reservoirs [119].

There is an opportunity to build on knowledge gained from taking action and observing changes in measured values. Managing fish populations so they have value in removing phosphorus from the lake as well as recreational value may require some actions followed by observations. Experience and ongoing investigation may be needed to develop monitoring systems that are both cost effective and sufficient to get the data needed for effective management of water quality. Developing a plan with a sufficient budget to be able to take action that is beneficial may be a challenge because of economic externalities. There is often significant value in maintaining water quality that allows drinking water and recreational use, avoids odors and is visually pleasing.

\section{Conclusion}

Active monitoring and management of lakes and reservoirs can be accomplished using ecological engineering principles. Complex lake and reservoir ecosystems must be characterized, monitored and managed with recognition of their dynamic behavior, the complexity of the ecosystem and the importance of reducing phosphorus and nitrogen concentrations. The difficulty of maintaining good water quality and preventing eutrophication increases as nutrient, and particularly phosphorus, concentrations increase. The current status of lake and ecosystem management has been reviewed and important methods have been enumerated. Important active management methods include precipitation of phosphorus with modified clays, solar powered circulation, removal of phosphorus by stocking and harvesting fish, nurturing macrophytes, and active management of the entire ecosystem through monitoring and control. Further research is needed on this important topic.

\section{Acknowledgements}

Partial financial support was provided by National Science Foundation grant 


\section{EEC-1166549.}

\section{References}

[1] Adey, W.H., Kangas, P.C. and Mulbry, W. (2011) Algal Turf Scrubbing: Cleaning Surface Waters with Solar Energy While Producing a Biofuel. BioScience, 61, 434441. https://doi.org/10.1525/bio.2011.61.6.5

[2] Ahtianinen, H., Artell, J., Elmgren, R., Hasselstrom, L. and Hakansson, C. (2014) Baltic Sea Nutrient Reductions-What Should We Aim for? Journal of Environmental Management, 145, 9-23.

[3] American Public Health Association, American Water Works Association, and Water Environment Federation (2012) Standard Methods for the Examination of Water and Wastewater. American Water Works Association.

[4] Amrhein, C., Anderson, M. and Matsumoto, M. (2005) Final Report for Reducing Eutrophic Conditions of the Salton Sea. California Regional Water Quality Control Board, Colorado River Basin Region.

[5] Baker, J.P. and Schofield, C.L. (1982) Aluminum Toxicity to Fish in Acidic Waters. Water, Air, and Soil Pollution, 18, 289-309.

[6] Bakker, E.S., Sarneel, J.M., Gulati, R.D., Liu, Z. and van Donk, E. (2013) Restoring Macrophyte Diversity in Shallow Temperate Lakes: Biotic Versus Abiotic Contraints. Hydrobiologia, 710, 23-37. https://doi.org/10.1007/s10750-012-1142-9

[7] Bernes, C., Carpenter, S.R., Gardmark, A., Larsson, P., Persson, L., Skov, C. and van Donk, E. (2013) What Is the Influence on Water Quality in Temperate Eutrophic Lakes of a Reduction of Planktivorous and Benthivorous Fish? A Systematic Review Protocol. Environmental Evidence, 2, 9-23. https://doi.org/10.1186/2047-2382-2-9

[8] Bishop, W.M., McNabb, T., Cormican, I., Willis, B.E. and Hyde, S. (2014) Operational Evaluation of Phoslock Phosphorus Locking Technology in Laguna Niguel Lake, California. Water, Air, and Soil Pollution, 225, 1-12. https://doi.org/10.1007/s11270-014-2018-6

[9] Borics, G., Nagy, L., Miron, S., Grigorszky, I., Laszlo-Nagy, Z., Lukacs, B.A., Toth, L.G. and Varbiro, G. (2013) Which Factors Affect Phytoplankton Biomass in Shallow Eutrophic Lakes. Hydrobiologia, 714, 93-104. https://doi.org/10.1007/s10750-013-1525-6

[10] Boros, G., Sondergaard, M., Takacs, P., Vari, A. and Tatrai, I. (2011) Influence of Submerged Macrophytes, Temperature, and Nutrient Loading on the Development of Redox Potential Around the Sediment-Water Interface in Lakes. Hydrobiologia, 665, 117-127. https://doi.org/10.1007/s10750-011-0609-4

[11] Brylinsky, M. (2012) Evaluation of Two Test Kits for Measurement of Microcystin Concentrations. Nova Scotia Department of the Environment.

[12] Carpenter, S.R., Kithcell, J.F. and Hodgson, J.R. (1985) Cascading Trophic Interactions and Lake Productivity. BioScience, 35, 634-639.

https://doi.org/10.2307/1309989

[13] Catalano, M.J., Allen M.S., Schaus, M.H., Buck, D.G. and Beaver, J.R. (2010) Evaluating Short-Term Effects of Omnivorous Fish Removal on Water Quality and Zooplankton at a Subtropical Lake. Hydrobiologia, 655, 159-169. https://doi.org/10.1007/s10750-010-0418-1

[14] Chang, S.-C., Li, C.-H., Lin, J.-J., Li, Y.-H. and Lee, M.-R. (2013) Effective Removal of Microcystis Aeruginosa and Microcystin-LR Using Nanosilicate Platelets. Chemosphere, 99, 49-55. 
[15] Chen, F.-Z., Song, X.-L., Hu, Y.-H., Liu, Z.-W., and Qin, B.-Q. (2009) Water Quality Improvement and Phytoplankton Response in the Drinking Water Source in Meiliang Bay of Lake Taihu, China. Ecological Engineering, 35, 1637-1645.

[16] Chen, F., Shu, T., Jeppesen, E., Liu, Z. and Chen, Y. (2013) Restoration of a Subtropical Eutrophic Shallow Lake in China: Effects on Nutrient Concentrations and Biological Communities. Hydrobiologia, 718, 59-71.

https://doi.org/10.1007/s10750-013-1603-9

[17] Coops, H., Kerkum, F.C.M., vanden Berg, M.S. and van Splunder, I. (2007) Submerged Macrophyte Vegetation and the European Water Framework Directive: Assessment of Status and Trends in Shallow, Alkaline Lakes in the Netherlands. Hydrobiologia, 584, 395-402. https://doi.org/10.1007/s10750-007-0586-9

[18] Correll, D.L. (1998) The Role of Phosphorus in the Eutrophication of Receiving Waters: A Review. Journal of Environment Quality, 27, 261.

[19] Craig, J.F. (2008) A Short Review of Pike Ecology. Hydrobiologia, 601, 5-16. https://doi.org/10.1007/s10750-007-9262-3

[20] Davidson, K., Gowen, R.J., Harison, P.J., Fleming, L.E., Hoagland, P. and Moschonas, G. (2014) Anthropogenic Nutrients and Harmful Algae in Coastal Waters. Journal of Environmental Management, 146, 206-216.

[21] Davidson, T.A., Bennion, H., Jeppesen, E., Clarke, G.H., Sayer, C.D., Morley, D., Odgaard, B.V., Rasmussen, P., Rawcliffe, R., Salgado, J., Simpson, G.L. and Amsinck, S.L. (2011) The Role of Cladocerans in Tracking Long-Term Change in Shallow Lake Trophic Status. Hydrobiologia, 676, 299-315.

https://doi.org/10.1007/s10750-011-0851-9

[22] Davis, J.R. and Koop, K. (2006) Eutrophication in Australian Rivers, Reservoirs and Estuaries-A Southern Hemisphere Perspective on the Science and Its Implications. Hydrobiologia, 559, 23-76. https://doi.org/10.1007/s10750-005-4429-2

[23] De Backer, S., Teissier, S. and Triest, L. (2012) Stabilizing the Clear-Water State in Eutrophic Ponds after Biomanipulation: Submerged Vegetation versus Fish Recolonization. Hydrobiologia, 689, 161-176. https://doi.org/10.1007/s10750-011-0902-2

[24] De Backer, S., Teissier, S. and Triest, L. (2014) Identification of Total Phosphate, Submerged Vegetation Cover and Zooplankton Size Thresholds for Success of Biomanipulation in Peri-Urban Eutrophic Ponds. Hydrobiologia, 737, 281-296. https://doi.org/10.1007/s10750-013-1739-7

[25] DeBoom, C.S. and Wahl, D.H. (2014) Piscivore Enhancement Effects on Food Webs Depend on Planktivore Body Size and Species Composition in Replicated Whole Lake Experiments. Hydrobiologia, 736, 31-49. https://doi.org/10.1007/s10750-014-1885-6

[26] Diovisalvi, N., Bohn, V.Y., Piccolo, M.C., Perillo, G.M.E., Baigun, C. and Zagarese, H.E. (2015) Shallow Lakes from the Central Plains of Argentina: An Overview and Worldwide Comparative Analysis of their Basic Limnological Features. Hydrobiologia, 752, 5-20. https://doi.org/10.1007/s10750-014-1946-x

[27] Dodds, W.K., Bouska, W.W., et al. (2009) Eutrophication of U.S. Freshwaters: Analysis of Potential Economic Damages. Environmental Science \& Technology, 43, 12-19. https://doi.org/10.1021/es801217q

[28] Drábková, M., Admiraal, W. and Marsálek, B. (2007) Combined Exposure to Hydrogen Peroxide and Light-Selective Effects on Cyanobacteria, Green Algae, and Diatoms. Environmental Science \& Technology, 41, 309-314. https://doi.org/10.1021/es060746i

[29] Ebert, D. (2005) Introduction to Daphnia Biology. In: Ecology, Epidemiology and 
Evolution of Parasitism in Daphnia, NCBI, Bethesda.

[30] Fan, C., Zhang, L., Wang, J., Zheng, C., Gao, G. and Wang, S. (2004) Processes and Mechanism of Effects of Sludge Dredging on Internal Source Release in Lakes. Chinese Science Bulletin, 49, 1853-1859. https://doi.org/10.1007/BF03183413

[31] Fauzi, H., Svensson, G. and Rahman, A.A. (2010) "Triple Bottom Line" as "Sustainable Corporate Performance": A Proposition for the Future. Sustainability, 2, 1345-1360. https://doi.org/10.3390/su2051345

[32] Figueredo, C.C. and Giani, A. (2005) Ecological Interactions between Nile Tilapia (Oreochromis Niloticus, L.) and the Phytoplanktonic Community of the Furnas Reservoir (Brazil). Freshwater Biology, 50, 1391-1403. https://doi.org/10.1111/j.1365-2427.2005.01407.x

[33] Florida, L. (2007) A Beginner's Guide to Water Management: Fish Communities and Trophic State in Florida Lakes University of Florida, Department of Fisheries and Aquatic Sciences.

[34] Fragoso, C.R., Motta Marques, D.M.L., Ferreira, T.F., Janse, J.H. and Van Nes, E.H. (2011) Potential Effects of Climate Change and Eutrophication on a Large Subtropical Shallow Lake. Environmental Modelling \& Software, 26, 1337-1348.

[35] Galbraith, M.G. (1967) Size-Selective Predation on Daphnia by Rainbow Trout and Yellow Perch. Transactions of the American Fisheries Society, 96, 1-10. https://doi.org/10.1577/1548-8659(1967)96[1:SPODBR]2.0.CO;2

[36] Gao, Y., Zhu, G., Qin, B., Pang, Y., Gong, Z. and Zhang, Y. (2009) Effect of Ecological Engineering on the Nutrient Content of Surface Sediments in Lake Taihu, China. Ecological Engineering, 35, 1624-1630.

[37] Gao, J., Liu, Z. and Jeppesen, E. (2014) Fish Community Assemblages Changed but Biomass Remained Similar after Lake Restoration by Biomanipulation in a Chinese Tropical Eutrophic Lake. Hydrobiologia, 724, 127-140. https://doi.org/10.1007/s10750-013-1729-9

[38] Garcı-Villada, L., Rico, M., Altamirano, M., Sanchez-Martın, L., Lopez-Rodas, V. and Costas, E. (2004) Occurrence of Copper Resistant Mutants in the Toxic Cyanobacteria Microcystis aeruginosa: Characterization and Future Implications in the Use of Copper Sulphate as Algaecide. Water Research, 438, 2207-2213.

[39] Glibert, P., Anderson, D., Gentien, P., Granéli, E. and Sellner, K. (2005) The Global, Complex Phenomena of Harmful Algal Blooms. Oceanography, 18, 136-147. https://doi.org/10.5670/oceanog.2005.49

[40] Gulati, R.D. and van Donk, E. (2002) Lakes in the Nethrlands, Their Origin, Eutrophication, and Restoration: State-of-the-Art Review. Hydrobiogia, 478, 73-106. https://doi.org/10.1023/A:1021092427559

[41] Hasan, M.R. and Chakrabarti, R. (2009) Use of Algae and Aquatic Macrophytes as Feed in Small-Scale Aquaculture, FAO Fisheries and Aquaculture. Technical Paper 531, Food and Agriculture Organization of the United Nations.

[42] Havens, K.E. and Beaver, J.R. (2013) Zooplankton to Phytoplankton Biomass Ratios in Shallow Florida Lakes: An Evaluation of Seasonality and Hypotheses about Factors Controlling Variability. Hydrobiologia, 703, 177-187. https://doi.org/10.1007/s10750-012-1357-9

[43] Hudek, K., Davis, L.C., Ibbini, J. and Erickson, L. (2014) Commercial Products from Algae. In: Bajpai, R.K., Prokop, A. and Zappi, M.E., Eds., Algal Biorefineries, Vol. 1, Springer, Dordrecht, 275-295.

[44] Hudnell, H.K., Green, D., Vien, R., Butler, S., Rahe, G., Richards, B.A. and Bleth, J. (2011) Improving Wastewater Mixing and Oxygenation Efficiency with So- 
lar-Powered Circulation. Clean Technologies and Environmental Policy, 13, 731742. https://doi.org/10.1007/s10098-010-0345-X

[45] Hudnell, H.K. (2010a) The State of U.S. Freshwater Harmful Algal Blooms Assessments, Policy and Legislation. Toxicon, 55, 1024-1034.

[46] Hudnell, H.K., Jones, C., Labisi, B., Lucero, V., Hill, D.R. and Eilers, J. (2010) Freshwater Harmful Algal Bloom (FHAB) Suppression with Solar Powered Circulation (SPC). Harmful Algae, 9, 208-217.

[47] Hudnell, H.K. (2008) Cyanobacterial Harmful Algal Blooms: State of the Science and Research Needs. Springer, New York.

[48] Huo, S., Ma, C., Xi, B., Su, J., Zan, F., Ji, D. and He, Z. (2013) Establishing Eutrophication Assessment Standards for Four Lake Regions, China. Journal of Environmental Sciences, 25, 2014-2022.

[49] Immers, A.K., Van der Sande, M.T., Van der Zande, R.M., Geurts, J.J.M., Van Donk, E. and Bakker, E.S. (2013) Iron Addition as a Shallow Lake Restoration Measure: Impacts on Charophyte Growth. Hydrobiologia, 710, 241-251. https://doi.org/10.1007/s10750-011-0995-7

[50] Jeppesen, E., Noges, P., Davidson, T.A., Haberman, J., Noges, T., Blank, K., Lauridsen, T.L., Sondergaard, M., Sayer, C., Laugaste, R., Johansson, L.S., Bjerring, R. and Amsinck, S.L. (2011) Zooplankton as Indicators in Lakes: A Scientific Plea for Including Zooplankton in the Ecological Quality Assessment of Lakes According to the European Water Framework Directive. Hydrobiologia, 676, 279-297.

https://doi.org/10.1007/s10750-011-0831-0

[51] Jeppesen, E., Sondergaard, M., Mazzeo, N., Meerhoff, M., Branco, C.C., Huszar, V. and Scasso, F. (2005) Lake Restoration and Biomanipulation in Temperate Lakes: Relevance for Subtropical and Tropical Lakes. In: Reddy, M.V., Ed., Restoration and Management of Tropical Eutropic Lakes, Science, Enfield, 341-359.

[52] Jeppesen, E., Meerhoff, M., Jacobsen, B.A., Hansen, R.S., Søndergaard, M., Jensen, J.P. and Branco, C.W.C. (2007) Restoration of Shallow Lakes by Nutrient Control and Biomanipulation-The Successful Strategy Varies with Lake Size and Climate. Hydrobiologia, 581, 269-285. https://doi.org/10.1007/s10750-006-0507-3

[53] Jobgen, A.M., Palm, A. and Melkonian, M. (2004) Phosphorus Removal from Eutrophic Lakes Using Periphyton on Submerged Artifical Substrata. Hydrobiologia, 528, 123-142. https://doi.org/10.1007/s10750-004-2337-5

[54] Jung, D., Cho, A., Zo, Y.G., Choi, S.I. and Ahn, T.S. (2009) Nutrient Removal from Polluted Stream Water by Artificial Aquatic Food Web System. Hydrobiologia, 630, 149-159. https://doi.org/10.1007/s10750-009-9788-7

[55] Kennison, G.C.B., Dunsford, D.S. and Schutten, J. (1998) Stable or Changing Lakes? A Classification of Aquatic Macrophyte Assemblages from a Eutrophic Shallow Lake System in the United Kingdom. Aquatic Conservation-Marine and Freshwater Ecosystems, 8, 669-684. https://doi.org/10.1002/(SICI)1099-0755(199809/10)8:5<669::AID-AQC307>3.0.CO $\underline{; 2-2}$

[56] Kuo, J., Hsieh, P. and Jou, W. (2008) Lake Eutrophication Management Modeling Using Dynamic Programming. Journal of Environmental Management, 88, 677687.

[57] Lathrop, R.C., Liebl, D.S., and Welke, K. (2013) Carp Removal to Increase Water Clarity in Shallow Eutrophic Lake Wingra. Lakeline, 23-30.

[58] Lazzaro, X. (1987) A Review of Planktivorous Fishes: Their Evolution, Feeding Behaviours, Selectivities, and Impacts. Hydrobiologia, 146, 97-167. 
https://doi.org/10.1007/BF00008764

[59] Li, P., Wei, J., Chiu, Y., Su, H., Peng, F. and Lin, J. (2010) Evaluation on Cytotoxicity and Genotoxicity of the Exfoliated Silicate Nanoclay. ACS Applied Materials \& Interfaces, 2, 1608-1613. https://doi.org/10.1021/am1001162

[60] Li, X., Song, H., Li, W., Lu, X. and Nishimura, O. (2010) An Integrated Ecological Floating-Bed Employing Plant, Freshwater Clam and Biofilm Carrier for Purification of Eutrophic Water. Ecological Engineering, 36, 382-390.

[61] Li, Z., Li, Y., Huang, W. and Sang, L. (2013) Artificial Floating Islands: A Technology for Clean Water and Agricultural Production in Rural China. International Journal of Environmental Protection, 3, 7-14.

[62] Lopez, C.B., Jewett, E.B., Dortch, Q., Walton, B.T. and Hudnell, H.K. (2008) Scientific Assessment of Freshwater Harmful Algal Blooms. Interagency Working Group on Harmful Algal Blooms, Hypoxia, and Human Health of the Joint Subcommittee on Ocean Science and Technology, Washington DC.

[63] Lu, K., Jin, C., Dong, S., Gu, B. and Bowen, S.H. (2006) Feeding and Control of Blue-Green Algal Blooms by Tilapia (Oreochromis niloticus). Hydrobiologia, 568, 111-120. https://doi.org/10.1007/s10750-006-0023-5

[64] McNabb, T. (2011) A New Tool for Proactive Water Quality Restoration: Algae Management. Lake and Water, 55, 18-23.

[65] McNeary, W.W. and Erickson, L.E. (2013) Sustainable Management of Algae in Eutrophic Ecosystems. Journal of Environmental Protection, 4, 9-19. https://doi.org/10.4236/jep.2013.411A002

[66] Meijer, M.L., de Boois, I., Scheffer, M., Portielje, R. and Hosper, H. (1999) Biomanipulation in Shallow Lakes in the Netherlands: An Evaluation of 18 Case Studies. Hydrobiologia, 408, 13-30.

[67] Mendiondo, E.M. (2014) Global Review of Lake and Reservoir Eutrophication and Associated Management Challenges. https://www.researchgate.net

[68] Moos, M.T., Taffs, K.H., Longstaff, B.J. and Ginn, B.K. (2014) Establishing Ecological Reference Conditions and Tracking Post-Application Effectiveness of Lanthanum-Saturated Bentonite Clay (Phoslock) for Reducing Phosphorus in Aquatic Systems: An Applied Paelolimnological Approach. Journal of Environmental Management, 141, 77-85.

[69] Morris, K., Bailey, P.C.E., Boon, P.I. and Hughes, L. (2006) Effects of Plant Harvesting and Nutrient Enrichment on Phytoplankton Community Structure in a Shallow Urban Lake. Hydrobiologia, 571, 77-91. https://doi.org/10.1007/s10750-006-0230-0

[70] Nakai, S., Zou, G., Song, X., Pan, Q., Zhou, S. and Hosomi, M. (2008) Release of Anti-Cyanobacterial Allelochemicals from Aquatic and Terrestrial Plants Applicable for Artificial Islands. Journal of Water and Environment Technology, 6, 55-63. https://doi.org/10.2965/jwet.2008.55

[71] Niemisto, J., Tamminen, P., Ekholm, P. and Horppila, J. (2012) Sediment Resuspension: Rescue of Downfall of a Thermally Stratified Eutrophic Lake. Hydrobiologia, 686, 267-276. https://doi.org/10.1007/s10750-012-1021-4

[72] Nixon, S.W. (1995) Coastal Marine Eutrophication: A Definition, Social Causes, and Future Concerns. Ophelia, 41, 199-219. https://doi.org/10.1080/00785236.1995.10422044

[73] Nyarumbu, T.O. and Magadza, C.H.D. (2016) Using the Planning and Management Model of Lakes and Reservoirs (PAMOLARE) as a Tool for Planning and Rehabilitation of Lake Chivero, Zimbabwe. Environmental Nanotechnology, Monitoring 
and Management, 5, 1-12.

[74] Ohio EPA, Division of Surface Water Compliance Assistance Unit, Division of Environmental and Financial Assistance and Ohio Rural Water Association (2004) Solar Bee SB10000W Pond Re-Circulating Pump Evaluation. Rockford, Ohio, Web. 9 July 2014.

[75] Olin, M., Rask, M., Ruuhijarvi, J., Keskitalo, J., Horppila, J., Tallberg, P., Taponen, T., Lehtovaara, A. and Sammalkorpi, I. (2006) Effects of Biomanipulation on Fish and Plankton Communities in Ten Eutrophic Lakes of Southern Finland. Hydrobiologia, 553, 67-88. https://doi.org/10.1007/s10750-005-0786-0

[76] Paerl, H.W. and Huisman, J. (2008) Blooms Like It Hot. Science, 320, 57-58. https://doi.org/10.1126/science.1155398

[77] Paerl, H.W. (2008) Nutrient and Other Environmental Controls of Harmful Cyanobacterial Blooms along the Freshwater-Marine Continuum. Advances in Experimental Medicine and Biology, 619, 217-237.

https://doi.org/10.1007/978-0-387-75865-7_10

[78] Patterson, J.J., Smith, C. and Bellamy, J. (2013) Understanding Enabling Capacities for Managing the "Wicked Problem" of Nonpoint Source Water Pollution in Catchments: A Conceptual Framework. Journal of Environmental Management, 128, 441-452.

[79] Pedusaar, T., Sammalkorpi, I., Hautala, A., Salujoe, J., Jarvalt, A. and Pihlak, M. (2010) Shifts in Water Quality in a Drinking Reservoir during and after Removal of Cyprinids. Hydrobiologia, 649, 95-106. https://doi.org/10.1007/s10750-010-0231-x

[80] Peretyatko, A., Teissier, S., De Backer, S. and Triest, L. (2009) Restoration Potential of Biomanipulation for Eutrophic Peri-Urban Ponds: The Role of Zooplankton Size and Submerged Macrophyte Cover. Hydrobiologia, 634, 125-135. https://doi.org/10.1007/s10750-009-9888-4

[81] Perovich, G., Dortch, Q., Goodrich, J., Berger, P.S., Brooks, J., Evens, T.J., Gobler, C.J., Graham, J., Hyde, J., Karner, D., O’Shea, D.K., Paul, V., Paerl, H., Piehler, M., Rosen, B.H., Santelmann, M., Tester, P. and Westrick, J. (2008) Causes, Prevention, and Mitigation Workgroup Report. Advances in Experimental Medicine and Biology, 619, 185-216. https://doi.org/10.1007/978-0-387-75865-7_9

[82] Perrow, M.R., Meijer, M.L., Dawidowicz, P. and Coops, H. (1997) Biomanipulation in Shallow Lakes: State of the Art. Hydrobiologia, 342, 355-365. https://doi.org/10.1023/A:1017092802529

[83] Pope, K.L., Lochmann, S.E. and Young, M.K. (2010) Methods for Assessing Fish Populations. Nebraska Cooperative Fish \& Wildlife Research Unit-Staff Publications.

[84] Portielje, R. and Van der Molen, D.T. (1999) Relationships between Eutrophication Variables: From Nutrient Loading to Transparency. Hydrobiologia, 408, 375-387. https://doi.org/10.1023/A:1017090931476

[85] Qin, B. (2009) Lake Eutrophication: Control Countermeasures and Recycling Exploitation. Ecological Engineering, 35, 1569-1573.

[86] Qin, B., Yang, L., Chen, F., Zhu, G., Zhang, L. and Chen, Y. (2006) Mechanism and Control of Lake Eutrophication. Chinese Science Bulletin, 51, 2401-2412. https://doi.org/10.1007/s11434-006-2096-y

[87] Rao, W., Ning, J., Zhong, P., Jeppesen, E. and Liu, Z. (2015) Size-Dependent Feeding of Omnivorous Nile Tilapia in a Macrophyte-Dominated Lake: Implications for Lake Management. Hydrobiologia, 749, 125-134.

[88] Renella, A.M. and Quiros, R. (2002) Relations between Planktivorous Fish and 
Zooplankton in Two Very Shallow Lakes of the Pampa Plain. Verhandlungen des Internationalen Verein Limnologie, 28, 1-5.

[89] Salerno, F., Viviano, G., Carrero, E., Manfredi, E.C., Lami, A., Musazzi, S., Marchetto, A., Guyennon, N., Tartari, G. and Copetti, D. (2014) Totla Phosphorus Reference Condition for Subalpine Lakes: A Comparison Among Traditional Methods and a New Process-Based Watershed Approach. Journal of Environmental Management, 145, 94-105.

[90] Schindler, D.W. (2012) The Dilemma of Controlling Cultural Eutrophication of Lakes. Proceedings of the Royal Society B: Biological Sciences, 279, 4322-4333. https://doi.org/10.1098/rspb.2012.1032

[91] Schindler, D.W., Hecky, R.E., Findlay, D.L., Stainton, M.P., Parker, B.R., Paterson, M.J., Beaty, K.G., Lyng, M. and Kasian, S.E.M. (2008) From the Cover: Eutrophication of Lakes Cannot Be Controlled by Reducing Nitrogen Input: Results of a 37-Year Whole-Ecosystem Experiment. Proceedings of the National Academy of Sciences, 105, 11254-11258. https://doi.org/10.1073/pnas.0805108105

[92] Schinkler, D.W. (2006) Recent Advances in the Understanding and Management of Eutrophication. Limnology and Oceanography, 51, 356-363. https://doi.org/10.4319/1o.2006.51.1_part_2.0356

[93] Schrage, L.J. and Downing, J.A. (2004) Pathways of Increased Water Clarity after Fish Removal from Ventura Marsh: A Shallow Eutophic Wetland. Hydrobiologia, 511, 215-231. https://doi.org/10.1023/B:HYDR.0000014065.82229.c2

[94] Schriver, P., Bogestrand, J., Jeppesen, E. and Sondergaard, M. (1995) Impact of Submerged Macrophytes on Fish-Zooplanl Phytoplankton Interactions: Large-Scale Enclosure Experiments in a Shallow Eutrophic Lake. Freshwater Biology, 33, 255270. https://doi.org/10.1111/j.1365-2427.1995.tb01166.x

[95] Seda, J., Hejzlar, J. and Kubecka, J. (2000) Trophic Structure of Nine Czech Reservoirs Regularly Stocked with Piscivorous Fish. Hydrobiologia, 429, 141-149. https://doi.org/10.1023/A:1004048415779

[96] Seidl, R. (2014) The Shape of Ecosystem Management to Come: Anticipating Risks and Fostering Resilience. BioScience, 64, 1159-1169.

https://doi.org/10.1093/biosci/biu172

[97] Smith, V.H. (2003) Eutrophication of Freshwater and Coastal Marine Ecosystems a Global Problem. Environmental Science and Pollution Research, 10, 126-139. https://doi.org/10.1065/espr2002.12.142

[98] Smith, V.H., Tilman, G.D. and Nekola, J.C. (1999) Eutrophication: Impacts of Excess Nutrient Inputs on Freshwater, Marine, and Terrestrial Ecosystems. Environmental Pollution, 100, 179-196.

[99] Sondergaard, M., Bjerring, R. and Jeppesen, E. (2013) Persistent Internal Phosphorus Loading During Summer in Shallow Eutrophic Lakes. Hydrobiologia, 710, 95107. https://doi.org/10.1007/s10750-012-1091-3

[100] Song, H., Li, X., Lu, X. and Inamori, Y. (2009) Investigation of Microcystin Removal from Eutrophic Surface Water by Aquatic Vegetable Bed. Ecological Engineering, 35, 1589-1598.

[101] Spears, B.M., Carvalho, L., Dudley, B. and May, L. (2013) Variation in Chlorophyll a to Total Phosphorus Ratio across $94 \mathrm{UK}$ and Irish Lakes: Implications for Lake Management. Journal of Environmental Management, 115, 287-294.

[102] Sterner, R.W. and George, N.B. (2000) Carbon Nitrogen, and Phosphorus Stoichiometry of Cyprinid Fishes. Ecology, 81, 127-140.

https://doi.org/10.1890/0012-9658(2000)081[0127:CNAPSO]2.0.CO;2 
[103] Strecker, R.G., Steichen, J.M., Garton, J.E. and Rice, C.E. (1977) Improving Lake Water Quality by Destratification. Transactions of the ASAE, 20, 713-720. https://doi.org/10.13031/2013.35634

[104] Strock, K.E. Saros, J.E., Simon, K.S., McGowan, S. and Kinneson, M.T. (2013) Cascading Effects of Generalist Fish Introduction in Oligotrophic Lakes. Hydrobiologia, 711, 99-113. https://doi.org/10.1007/s10750-013-1469-x

[105] Tatrai, I., Matyas, K., Korponai, J., Paulovits, G., Pomogyi, P. and Pekar, F. (2003) Management of Fish Communities and its Impacts on the Lower Trophic Levels in Shallow Ecosystems in Hungary. Hydrobiologia, 506-509, 489-496. https://doi.org/10.1023/B:HYDR.0000008616.52608.51

[106] Teissier, S., Peretyatko, A., De Backer, S. and Triest L. (2012) Strength of Phytoplankton-Nutrient Relationship: Evidence from 13 Biomanipulated Ponds. Hydrobiologia, 689, 147-159. https://doi.org/10.1007/s10750-011-0726-0

[107] Ter Heerdt, G. and Hootsmans, M. (2007) Why Biomanipulation Can Be Effective in Peaty Lakes. Hydrobiologia, 584, 305-316. https://doi.org/10.1007/s10750-007-0594-9

[108] Toffolon, M., Ragazzi, M., Righetti, M., Teodoru, C.R., Tubino, M., Defrancesco, C. and Pozzi, S (2013) Effects of Artificial Hypolimnetic Oxygenation in a Shallow Lake. Part 1: Phenomenological Description and Management. Journal of Environmental Management, 114, 520-529.

[109] Touchette, B.W., Edwards, C.T. and Alexander, J. (2008) A Comparison of Cyanotoxin Release Following Bloom Treatment with Copper Sulfate or Sodium Carbonate Peroxyhdrate. In: Hudnell, H.K., Ed., Cyanobacterial Harmful Algal Blooms: State of the Science and Research Needs, Springer, New York, 314-315.

[110] U.S. Environmental Protection Agency (U.S. EPA) (2009) National Lakes Assessment: A Collaborative Survey of the Nation's Lakes. EPA 841-R-09-001, U.S. Environmental Protection Agency, Office of Water and Office of Research and Development, Washington DC.

[111] U.S. Environmental Protection Agency (U.S. EPA) (2010) National Lakes Assessment: Technical Appendix. 841-R-09-001a, U.S. Environmental Protection Agency, Office of Water and Office of Research and Development, Washington DC.

[112] U.S. Global Change Research Program (2014) 2014 National Climate Assessment.

[113] U.S. Environmental Protection Agency (U.S. EPA) (2012) Cyanobacteria and Cyanotoxins: Information for Drinking Water Systems. EPA-810F11001, Office of Water, Washington DC.

[114] U.S. EPA (2000) Nutrient Criteria Technical Guidance Document-Lakes. EPA-822-B00-001, Washington DC.

[115] U.S. EPA (2000) Wastewater Technology Fact Sheet: Free Water Surface Wetlands. United States Environmental Protection Agency.

[116] Van de Haterd, R.J.W. and Ter Heerdt, G.N.J. (2007) Potential for the Development of Submerged Macrophytes in Eutrophicated Shallow Peaty Lakes after Restoration Measures. Hydrobiologia, 584, 277-290. https://doi.org/10.1007/s10750-007-0593-x

[117] Van Liere, L. and Janse, J.H. (1992) Restoration and Resilience to Recovery of the Lake Loosdrecht Ecosystem in Relation to its Phosphorus Flow. Hydrobiologia, 233, 95-104. https://doi.org/10.1007/BF00016099

[118] Ventela, A.M., Kirkkala, T., Lendasse, A., Tarvainen, M., Helminen, H. and Sarvala, J. (2011) Climate-Related Challenges in Long-term Management of Sakylan Pyhajarvi (SW Finland). Hydrobiologia, 660, 49-58.

https://doi.org/10.1007/s10750-010-0415-4 
[119] Verdonschot, P.F.M., Spears, B.M., Feld, C.K., Brucet, S., Keizer-Vlek, H., Borja, A., Elliott, M., Kernan, M. and Johnson, R.K. (2013) A Comparative Review of Recovery Processes in Rivers, Lakes, Estuarine and Coastal Waters. Hydrobiologia, 704, 453-474. https://doi.org/10.1007/s10750-012-1294-7

[120] Wang, C., Bai, L. and Pei, Y. (2013) Assessing the Stability of Phosphorus in Lake Sediments Amended with Water Treatment Residuals. Journal of Environmental Management, 122, 31-36.

[121] Wang, S., Jiao, L.X., Yang, S., Jin, X. and Yi, W. (2012) Effects of Organic Matter and Submerged Macrophytes on Variation of Alkaline Phosphatase Activity and Phosphorus Fractions in Lake Sediment. Journal of Environmental Management, 113, 355-360.

[122] Wang, S.H., Huggins, D.G., DeNoyelles, F., Meyer, J.O. and Lennon, J.T. (2000) Assessment of Clinton Lake and Its Watershed. Report No. 96, University of Kansas, Lawrence.

[123] Wang, X., Bai, S., Lu, X., Li, Q., Zhang, X. and Yu, L. (2008) Ecological Risk Assessment of Eutrophication in Songhua Lake, China. Stochastic Environmental Research and Risk Assessment, 22, 477-486.

https://doi.org/10.1007/s00477-007-0147-9

[124] Wang, Z., Li, D., Qin, H. and Li, Y. (2012) An Integrated Method for Removal of Harmful Cyanobacterial Blooms in Eutrophic Lakes. Environmental Pollution, 160, 34-41.

[125] Wersal, R.M. and Madsen, J.D. (2012) Aquatic Plants: Their Uses and Risks, International Plant Protection Convention. Food and Agriculture Organization of the United Nations.

[126] Xia, R., Zhang, Y., Critto, A., Wu, J., Fan, J., Zheng, Z. and Zhang, Y. (2016) The Potential Impacts of Climate Change Factors on Freshwater Eutrophication: Implications for Research and Countermeasures of Water Management in China. Sustainability, 8, 229.

[127] Xie, P. and Liu, J. (2001) Practical Success of Biomanipulation Using Filter-Feeding Fish to Control Cyanobacteria Blooms: A Synthesis of Decades of Research and Application in a Subtropical Hypereutrophic Lake. The Scientific World Journal, 1, 337-356. https://doi.org/10.1100/tsw.2001.67

[128] YSI (2014) The Basics of Chlorophyll Measurement. www.ysi.com

[129] Yuan, X., Pan, G., Chen, H. and Tian, B. (2009) Phosphorus Fixation in Lake Sediments Using LaCl3-Modified Clays. Ecological Engineering, 35, 1599-1602.

[130] Yuan, Y., Locke, M.A., Bingner, R.L. and Rebich, R.A. (2013) Phosphorus Losses from Agricultural Watersheds in the Mississippi Delta. Journal of Environmental Management, 115, 14-20.

[131] Zanchett, G. and Oliveira-Filho, E. (2013) Cyanobacteria and Cyanotoxins: From Impacts on Aquatic Ecosystems and Human Health to Anticarcinogenic Effects. Toxins, 5, 1896-1917. https://doi.org/10.3390/toxins5101896

[132] Zhou, Q., Xie, P., Xu, J., Ke, Z., Guo, L. and Cao, T. (2009) Seasonal Variations in Stable Isotope Ratios of Two Biomanipulation Fishes and Seston in a Large Pen Culture in Hypereutrophic Meiliang Bay, Lake Taihu. Ecological Engineering, 35, 1603-1609. 
Submit or recommend next manuscript to SCIRP and we will provide best service for you:

Accepting pre-submission inquiries through Email, Facebook, LinkedIn, Twitter, etc. A wide selection of journals (inclusive of 9 subjects, more than 200 journals)

Providing 24-hour high-quality service

User-friendly online submission system

Fair and swift peer-review system

Efficient typesetting and proofreading procedure

Display of the result of downloads and visits, as well as the number of cited articles Maximum dissemination of your research work

Submit your manuscript at: http://papersubmission.scirp.org/

Or contact jep@scirp.org 